\title{
Why Has Female Enrollment in One Engineering Elective Increased to Al- most $80 \%$ Over the Past Six Years?
}

\section{Dr. Mark M. Budnik, Valparaiso University}

Mark M. Budnik is the Paul H. Brandt Professor of Engineering at Valparaiso University. Prior to joining the faculty at Valparaiso University in 2006, Mark worked in the semiconductor industry, culminating as a Principal Engineer and Director of White Goods and Motor Control at Hitachi Semiconductor. He is the author of more than fifty book chapters, journal articles, and conference proceedings. Mark's current research interests are in the field of creativity and innovation instruction. He is a Senior Member of the IEEE and a Fellow of the International Symposium on Quality Electronic Design. 


\title{
Why Has Female Enrollment in One Engineering Elective Increased to Almost $80 \%$ Over the Past Six Years?
}

\begin{abstract}
Over the past six years, one engineering elective at Valparaiso University has seen a dramatic, continuous increase in its female enrollment. While Valparaiso University's female engineering enrollment oscillates around the national average, enrollment in ECE490 (Innovation in Engineering Design) has risen steadily from $19 \%$ to $77 \%$.

The class introduces design as a multi-disciplinary concept and is open to all engineering majors. The first half of the semester is offered on Valparaiso University's campus. Students then participate in a five-day field trip, traveling from our midwest campus to Disneyland ${ }^{\odot}$ Resort in Anaheim, California, or Walt Disney World@ Resort in Lake Buena Vista, Florida. At the parks, students participate in multiple workshops and tours focusing on engineering, design, creativity, innovation, leadership, teamwork, and communication. Sessions are led by either Valparaiso University faculty or Disney Parks Cast Members. After returning to campus, students complete the final seven weeks of the semester at Valparaiso University.

This paper will provide a more detailed description of ECE490. This paper will also introduce several theories to explain the increasing enrollment of women in the class. We will present our conclusion that the increase in female enrollment is a result of a number of different factors, rather than one single reason.
\end{abstract}

\section{Introduction}

Like many other engineering programs, Valparaiso University has worked diligently to increase the enrollment of women and under-represented minorities in its exclusively undergraduate engineering programs. However, such enrollments have only oscillated about the national average over the past ten years. While there is slight variation from year-to-year, the distribution of the women enrolled in the various programs also mirrors national averages (see Table 1).

Table 1. Enrollment of Female Students, Male Students, and Percentage of Female Students by Undergraduate Engineering Major.

\begin{tabular}{|l|c|c|c|c|c|c|c|c|c|}
\hline \multirow{2}{*}{ Enginering Major } & \multicolumn{3}{|c|}{ Spring, 2015 } & \multicolumn{3}{c|}{ Spring, 2016 } & \multicolumn{3}{c|}{ Spring, 2017 } \\
\cline { 2 - 11 } & $\mathrm{F}$ & $\mathrm{F} \%$ & $\mathrm{M}$ & $\mathrm{F}$ & $\mathrm{F} \%$ & $\mathrm{M}$ & $\mathrm{F}$ & $\mathrm{F} \%$ & $\mathrm{M}$ \\
\hline Civil & 21 & $20.4 \%$ & 82 & 23 & $21.1 \%$ & 86 & 25 & $22.9 \%$ & 84 \\
\hline Computer & 6 & $22.2 \%$ & 21 & 9 & $20.0 \%$ & 36 & 9 & $14.3 \%$ & 54 \\
\hline Electrical & 16 & $13.9 \%$ & 99 & 15 & $14.0 \%$ & 92 & 16 & $15.8 \%$ & 85 \\
\hline Mechanical & 31 & $16.0 \%$ & 163 & 41 & $19.1 \%$ & 174 & 50 & $20.7 \%$ & 191 \\
\hline Undeclared & 1 & $12.5 \%$ & 7 & 2 & $9.1 \%$ & 20 & 0 & $0.0 \%$ & 5 \\
\hline Overall & 75 & $16.8 \%$ & 372 & 90 & $18.1 \%$ & 408 & 100 & $19.3 \%$ & 419 \\
\hline
\end{tabular}


Historically, female students at Valparaiso University have been distributed fairly evenly across the program's various electives. However, over the past six years, one engineering elective at Valparaiso University has seen a dramatic increase in its female enrollment (see Figure 1).

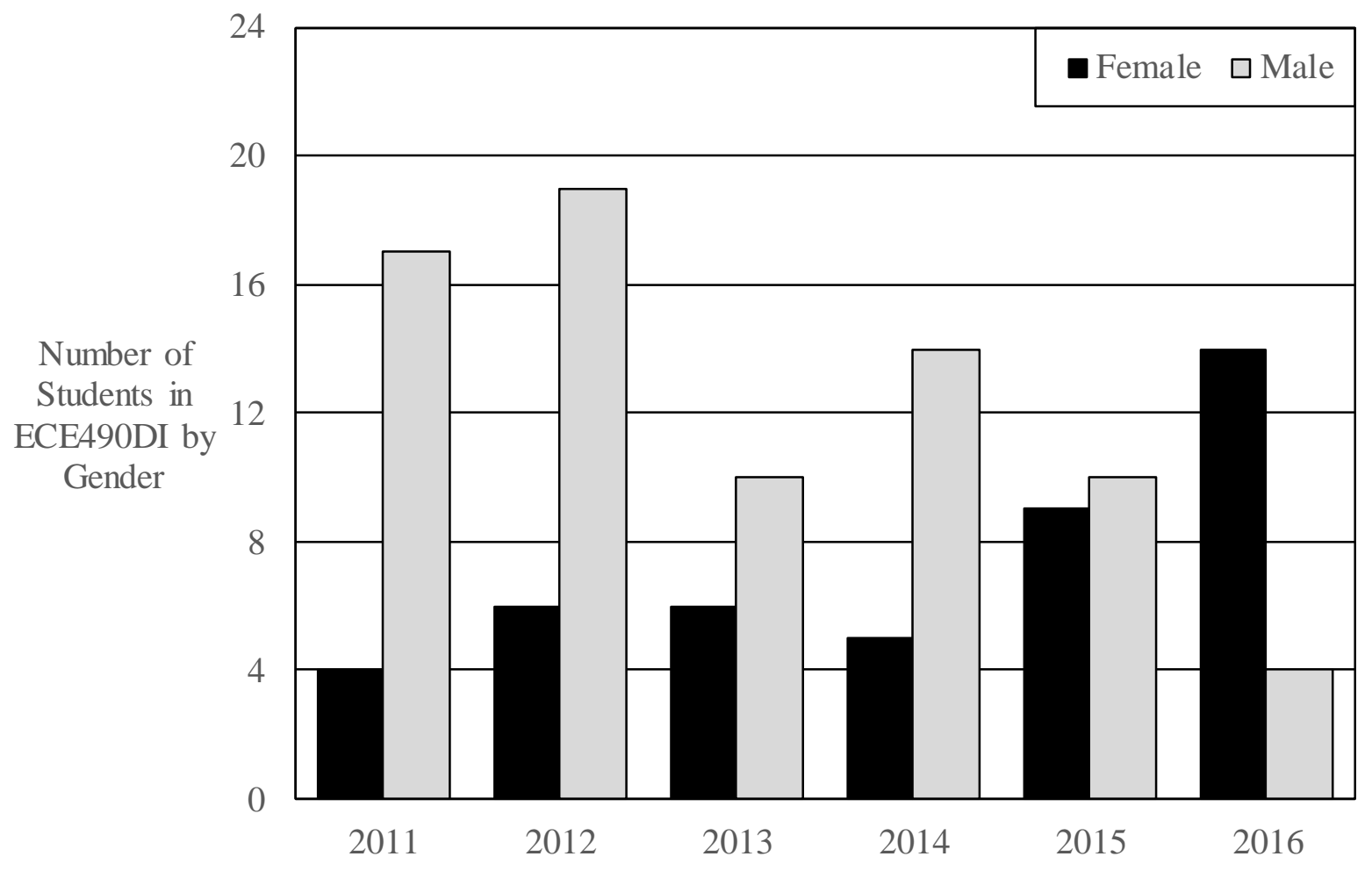

Figure 1. Enrollment by Gender in ECE490 (Innovation in the Engineering Design Process) at Valparaiso University. Note, each year, the student cap for the course was met, and the course was closed to additional enrollment.

ECE490 (Innovation in Engineering Design) was offered for the first time in 2011. The class introduces design as a multi-disciplinary concept and is open to all engineering majors. The first half of the semester is offered on Valparaiso University's campus. Students then participate in a five-day field trip, traveling from our midwest campus to Disneyland@ $\odot$ Resort in Anaheim, California, or Walt Disney World $\odot$ Resort in Lake Buena Vista, Florida. At the parks, students then participate in multiple workshops and tours focusing on engineering, design, creativity, innovation, leadership, teamwork, and communication. Sessions are led by either Valparaiso University faculty or Disney Parks Cast Members. After returning to campus, students complete the final seven weeks of the semester at Valparaiso University.

This paper will provide a more detailed description of ECE490. This paper will also introduce several theories to explain the increasing enrollment of women in the class. We will present our conclusion that the increase in female enrollment is a result of a number of different factors, rather than one single reason. 


\section{Innovation in Engineering Class}

After reviewing the National Academy of Engineering's The Engineer of 2020, Valparaiso University began to offer a course on innovation in the engineering design process. ${ }^{1,2,3,4,5,6}$ ECE490 / Innovation in the Engineering Design Process introduces engineering students to the multi-disciplinary engineering design process and the differences between creativity (doing / making something new) and innovation (doing/making something better). These simple definitions for creativity and innovation are easy for students to grasp from the first day of class and are readily applicable as students are challenged to define and explore creative and innovative steps in the engineering design process.

ECE490 is a one-credit class that is offered each fall semester. (An abbreviated course scheduled is shown in Figure 2). Prerequisites for the class are sophomore standing (or higher) and instructor approval, but it is primarily taken by junior and senior students (see Table 2). It is conducted as a laboratory class and meets for three hours once per week. The class is open to all engineering majors (bioengineering, civil engineering, computer engineering, electrical engineering, and mechanical engineering), and students who are sophomores, juniors, or seniors. The ECE Department presently awards electrical or computer engineering elective credit for ECE490. However, our other engineering departments (Mechanical and Civil) are concerned that as a multi-disciplinary course, ECE490 is not specific for their discipline, and will not allow their students to use the course to satisfy electives in their engineering major. Additionally, the Mechanical Engineering and Civil Engineering students cannot use the ECE490 course to fulfill any of their other free electives.

The class is advertised both through direct emails to the College of Engineering students and through signage in the College of Engineering laboratory. The course has been taught by the same male faculty member each year since its inception in 2011. He joined the institution in 2011 after nearly fifteen years in the electronics industry.

The course draws a lot of comparisons to our two-semester senior design sequence. However, there are significant differences between ECE490 and our capstone design classes. First, unlike senior design, ECE490 has a single course objective: Students will be able to apply the engineering design process. Second, it is a truly multi-disciplinary class, and in ECE490 engineers of all majors (bio, civil, computer, electrical, and mechanical) work on multidisciplinary teams developing solutions to real world problems.

One of the most significant differences between ECE490 and the senior design sequence is the scope of the engineering problems addressed. In our senior design classes, students are working on the same problem across the two semester sequence. In ECE490, problems are defined as case studies and can take anywhere from 30 minutes to two weeks. Giving students a larger number of smaller projects allows us to provide them with unique experiences in our curriculum. 


\begin{tabular}{|c|l|}
\hline Week & Topic \\
\hline 1 & Introduction to Engineering Design and Engineering Notebooks \\
\hline 2 & Engineering Design Process \\
\hline 3 & Identifying Problems and Needs \\
\hline 4 & Identifying Requirements and Constraints \\
\hline 5 & Specifying Requirements and Constraints \\
\hline 6 & Brainstorming \\
\hline 7 & Brainstorming \\
\hline 8 & Preparation for Class Field Trip \\
\hline 9 & Class Trip \\
\hline 10 & Selecting an Approach \\
\hline 11 & Selecting an Approach \\
\hline 12 & Engineering Models \\
\hline 13 & Engineering Models \\
\hline 14 & NO CLASS -- THANKSGIVING \\
\hline 15 & Iterating Your Design \\
\hline 16 & Presentations \\
\hline
\end{tabular}

Figure 2. ECE490 / Innovation in the Engineering Design Process Class Outline.

Table 2. Gender and Rank of Students Participating in ECE490 Over the Past Two Years.

\begin{tabular}{|l|c|c|c|c|c|c|c|c|c|c|c|c|}
\hline \multirow{2}{*}{ Enginering Major } & \multicolumn{6}{|c|}{ Fall, 2015 Trip } & \multicolumn{5}{|c|}{ Fall, 2016 Trip } \\
\cline { 2 - 19 } & Sophomore & \multicolumn{2}{|c|}{ Junior } & \multicolumn{2}{|c|}{ Senior } & \multicolumn{3}{|c|}{ Sophomore } & \multicolumn{2}{|c|}{ Junior } & \multicolumn{2}{|c|}{ Senior } \\
\cline { 2 - 18 } & $\mathrm{F}$ & $\mathrm{M}$ & $\mathrm{F}$ & $\mathrm{M}$ & $\mathrm{F}$ & $\mathrm{M}$ & $\mathrm{F}$ & $\mathrm{M}$ & $\mathrm{F}$ & $\mathrm{M}$ & $\mathrm{F}$ & $\mathrm{M}$ \\
\hline Civil & 0 & 0 & 0 & 0 & 0 & 1 & 1 & 0 & 1 & 0 & 0 & 0 \\
\hline Computer & 0 & 0 & 3 & 0 & 1 & 2 & 2 & 0 & 0 & 0 & 0 & 0 \\
\hline Electrical & 0 & 0 & 0 & 0 & 1 & 3 & 1 & 0 & 0 & 0 & & 2 \\
\hline Mechanical & 1 & 0 & 2 & 0 & 0 & 3 & 0 & 0 & 2 & 0 & 6 & 2 \\
\hline $\begin{array}{l}\text { Double Major } \\
\text { ECE + ME }\end{array}$ & 0 & 0 & 1 & 0 & 0 & 1 & 0 & 0 & 0 & 0 & 1 & 0 \\
\hline Total & 1 & 0 & 6 & 0 & 2 & 10 & 4 & 0 & 3 & 0 & 7 & 4 \\
\hline
\end{tabular}


For example, instead of working on one FMEA document for two weeks, students can develop subsets of different FMEAs over a 3-hour period. This gives students an opportunity to receive immediate feedback from the faculty member. ECE490's curriculum and classroom environment are specifically designed to provide a safe space for students to try, and sometimes fail, as they learn how engineering solutions are developed.

In senior design, teams are essentially static across the two semester sequence. In ECE490, teams are created and dissolved continuously through the semester (and sometimes in the same class period) as new case studies are presented to the students. Teams can be self-selected, created by the professor, or self-selected with restrictions. (For example, students may assemble their own teams, but cannot join with anyone sitting in their row.) Unlike senior design, which is taught by a faculty team, ECE490 is taught by a single faculty member so all students have a consistent experience.

However, the greatest difference between ECE490 and senior design (or any other class in our curriculum) is the mandatory off-site field trip conducted during our Fall Break. Students travel from our midwest campus to either Disneyland ${ }^{\odot}$ Resort in Anaheim, California, or Walt Disney World $^{\odot}$ Resort in Lake Buena Vista, Florida. An example itinerary is shown in Figure 3.

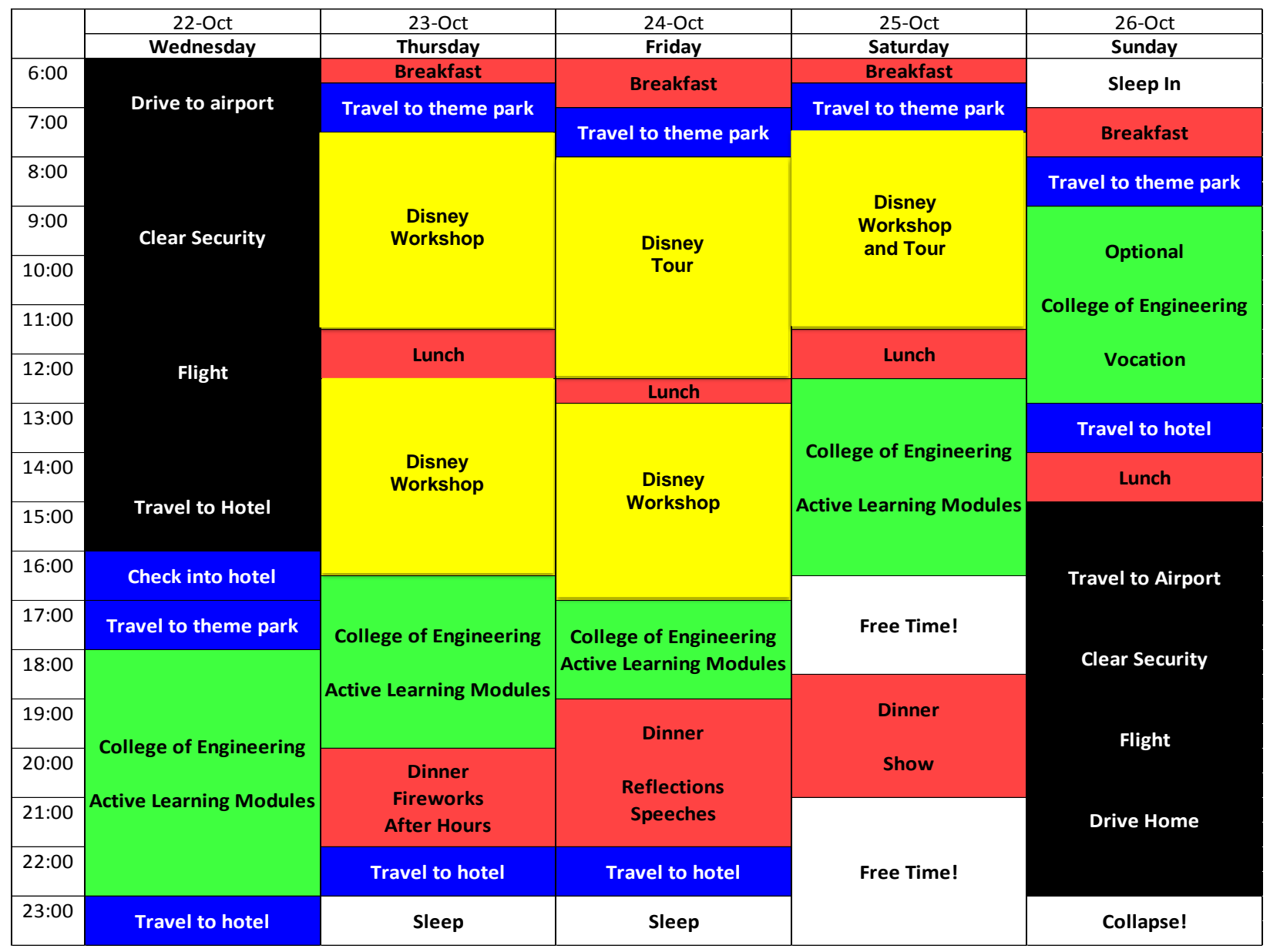

Figure 3. Example Class Trip Agenda to Disneyland ${ }^{\odot}$ Resort or Walt Disney World $^{\odot}$ Resort. $^{\circ}$ 
At the parks, students participate in multiple workshops and tours focusing on engineering, design, creativity, innovation, leadership, teamwork, and communication. Sessions are led by either Valparaiso University faculty or Disney Parks Cast Members. The trip is the highlight of the course and provides countless opportunities for students to see real-world applications of the engineering design process. To pay for the trip, students pay an additional fee that has averaged \$984. This price includes flights, hotel, theme park tickets, meals, and all workshops, tours, and discussion sessions. The price is offset by contributions from the Dean's Annual Fund, and partial scholarships have been donated by alumni.

Enrollment for ECE490 is always limited, but the enrollment is capped by specific activities scheduled by Valparaiso University at the Disney Parks. The cap has varied from 12 to 25 students over the six years the course has been offered.

The cost of the trip has varied by year. Over the six years, the lowest student cost was $\$ 899$, with a maximum cost of $\$ 1,099$. The average cost was $\$ 984$. In some years, financial assistance is available for students in need. This is a function of alumni generosity and funds from the Dean's Annual fund. Financial assistance packages have averaged \$255 over the six years the course has been offered.

Since the focus of this paper is the disproportionate enrollment of women in ECE490, we will not dedicate additional space here to the assessment of the course or how it can be replicated at the institutions. Rather, we refer interested readers to the references. ${ }^{1,2,3,4,5,6}$

\section{Female Enrollment in Electives}

In 2013, Valparaiso University offered its third iteration of the ECE490 class. At the start of the semester, it was noted that female enrollment in the class had climbed from $19 \%$ in the inaugural year to 38\% (see Figure 4). This seemed unusual, since Valparaiso University's College of Engineering female enrollment oscillates about the national average. In 2014, female enrollment in ECE490DI decreased to 26\%, but it was still above the Valparaiso University's College of Engineering average. In, 2015, the female enrollment percentage increased to $47 \%$, the highest percentage in any of our engineering electives. In 2016, female enrollment jumped futher to $77 \%$.

A study was performed by Valparaiso University to see how the female enrollment in ECE490 compared to its other engineering electives. For the 2015-2016 and the 2016-2017 academic years, female enrollment in the College of Engineering's electives average $17.2 \%$ with a median of $15.8 \%$ (see Figure 4). The two sections with the highest female enrollment over the past two years were ECE490. 


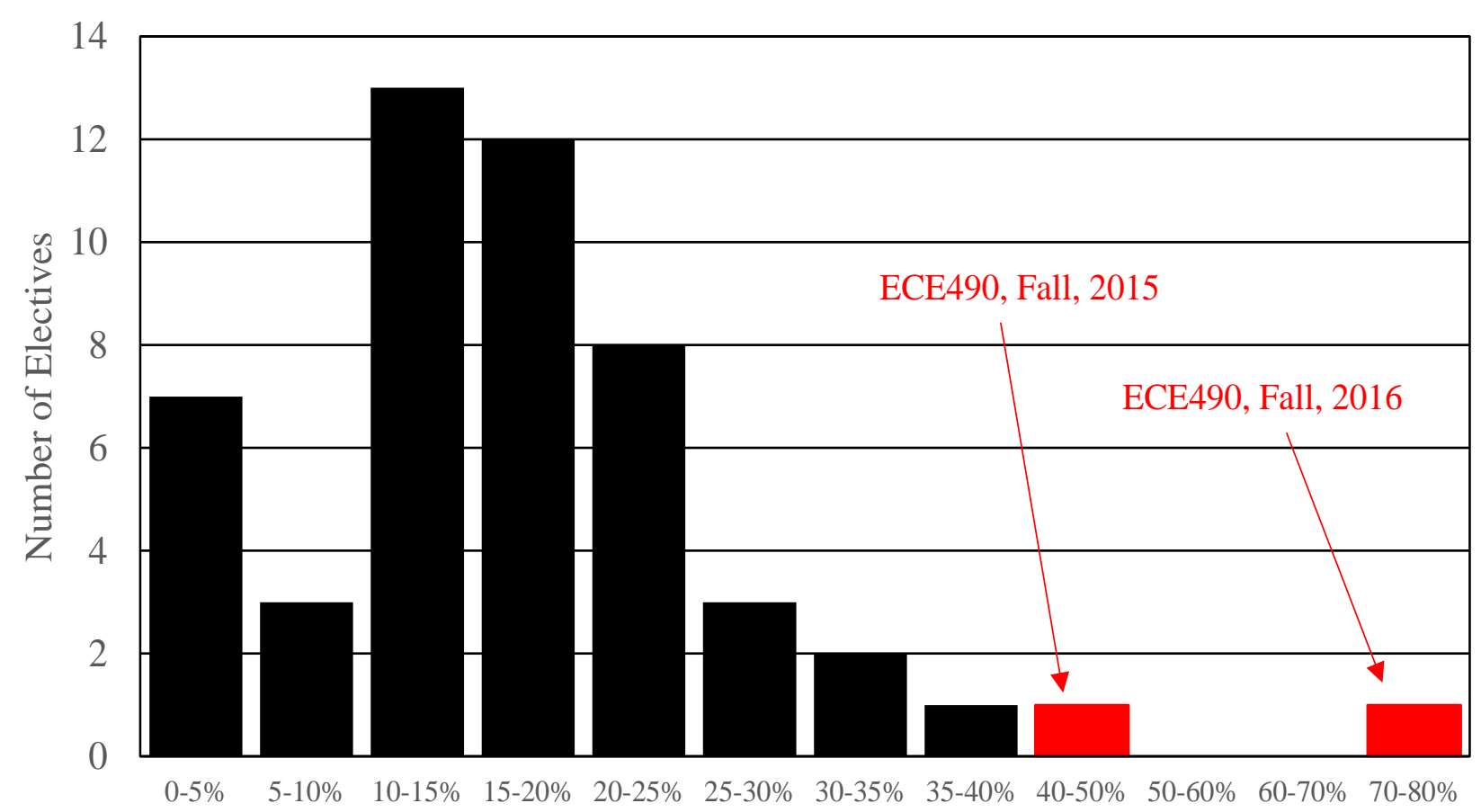

Figure 4. Pareto Analysis of Female Enrollment by Electives for Past Two Academic Years (2015-2016 and 2016-2017).

Surveys were conducted on 47 students who had or had not enrolled in the class in an attempt to determine the reason (or reasons) for the increase in ECE490 higher female enrollment. The survey consisted of ten questions and asked students to assess themselves on a Likert-type scale (1 was No, Definitely Not, and 5 was Yes, Definitely). Only six of the questions are used for our purposes. The other questions are shown below and were included to keep students from second guessing the purpose of the survey.
A) I know how to write a great lab report.
B) I always give my best in all of my classes.
C) I consider my work to be neat and organized.
D) While not perfect, I am comfortable with my math skills

The survey was anonymous and was given as a warm-up exercise in a different class with 7 female students and 40 male students. Two female and two male surveyed students had previously participated in the ECE490 class. The response rate was 100\%. The results are shown in Table 3. 
Table 3. Results of Student Survey.

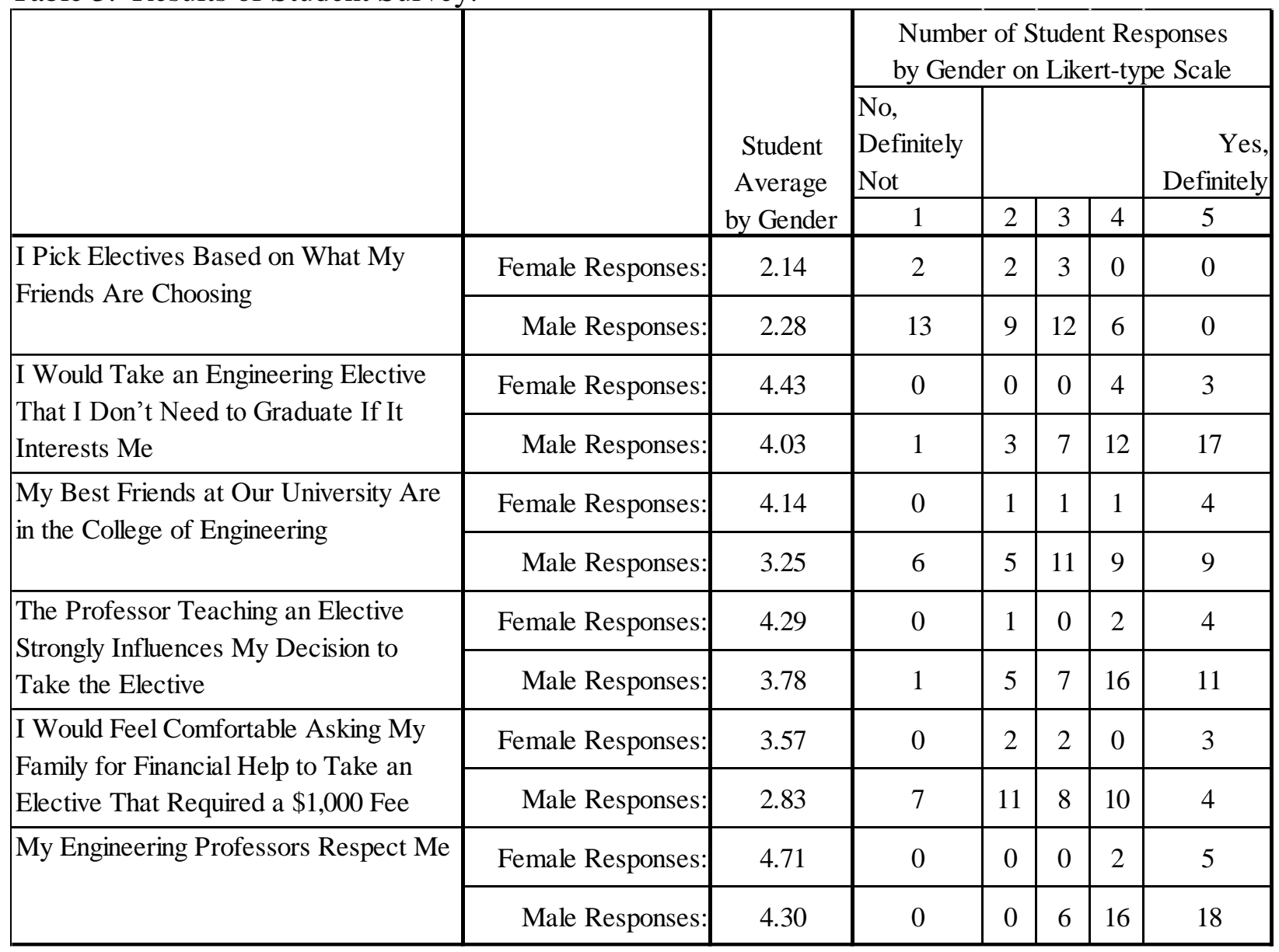

Additionally, the interviews of twenty female and twenty male students (all of which had participated in the trip) consisted of two open-ended questions

1) How can the class and trip be improved?

2) Why has the female enrollment grown to over $75 \%$ ?

The results of the surveys and interviews are shown together in Table 4. No single factor was identified as a dominant reason for high female enrollment, and almost every student highlighted four or more of the factors below. Multiple factors were found to contribute to higher enrollment of women. 
Table 4. Student Identified Factors Influencing Disproportionate Female Enrollment in ECE490.

\begin{tabular}{|c|c|}
\hline Factor & Comment \\
\hline It's Disney & $\begin{array}{l}\text { One factor that was immediately examined was the field trip to the Disney Parks. } \\
\text { Did the Disney content tend to attract more women than men? Feedback from all } \\
\text { students indicated that the Disney-focused content was a factor for those who } \\
\text { enrolled in the course. Alumni male students indicated that they had just as much } \\
\text { interest in the Disney content as the alumni women. However, feedback from } \\
\text { existing students indicated that there is growing pressure on male students in } \\
\text { secondary schools to embrace their masculinity and reject any choice or option that } \\
\text { might be deemed too feminine. Some male students admitted that this pressure } \\
\text { continues to be self-inflicted in college, so they chose not to enroll in the course, } \\
\text { even though they wanted to, because they did not want to appear effeminate. }\end{array}$ \\
\hline Cost & $\begin{array}{l}\text { ECE490 has had an average fee of } \$ 984 \text { over the past six years. As a whole, female } \\
\text { students and alumni strongly felt that they were more comfortable asking for } \\
\text { financial assistance from their families for significant, class related fees and } \\
\text { expenses. It was speculated by a number of women that parents are more likely to } \\
\text { be supportive of special requests from daughters than from sons because the } \\
\text { parents recognize how many other barriers women in engineering may have to face. }\end{array}$ \\
\hline $\begin{array}{l}\text { Cohorts of } \\
\text { Women }\end{array}$ & $\begin{array}{l}\text { In our surveys and interviews, women actually indicated that they would be less } \\
\text { likely than men to take elective classes based upon their friends' choices. } \\
\text { However, the women also indicated that they were much more likely to also have } \\
\text { their best friends in the College of Engineering. Male student responses indicated } \\
\text { they were much more likely to have best friends outside of the College of } \\
\text { Engineering. Therefore, while female students may like to work and participate as } \\
\text { cohorts, they are less likely to rely upon their College of Engineering friend's } \\
\text { elective choices when the women pick their own electives. }\end{array}$ \\
\hline Faculty Attitude & $\begin{array}{l}\text { A significant amount of effort at Valparaiso University is invested in building an } \\
\text { inclusive, welcoming environment. Therefore, it was welcome, but slightly } \\
\text { unexpected, that female students responded that they believed their professors } \\
\text { respected them more than the male students. However, women responded that they } \\
\text { were more likely to consider the faculty teaching an elective when selecting their } \\
\text { choices. The faculty member who has taught ECE490 since its inception is } \\
\text { recognized by female and male students as being a champion for diversity. }\end{array}$ \\
\hline $\begin{array}{l}\text { Willingness to } \\
\text { Enroll in } \\
\text { Electives Not } \\
\text { Required for } \\
\text { Major }\end{array}$ & $\begin{array}{l}\text { Women's responses also indicated that they were more likely than men to enroll in } \\
\text { an elective that they found interesting, even if it did not count toward their } \\
\text { graduation requirements. This is specifically a factor for bioengineering, civil } \\
\text { engineering, and mechanical engineering students who do not receive credit for the } \\
\text { class toward their engineering requirements. }\end{array}$ \\
\hline $\begin{array}{l}\text { Multidisciplinary } \\
\text { Course }\end{array}$ & $\begin{array}{l}\text { From its inception, ECE490 was conceived as a multidisciplinary course. Students } \\
\text { of all engineering majors have always been encouraged to enroll in the class. This } \\
\text { provides a larger pool of women that can enroll in the course than if ECE490 } \\
\text { enrollment was limited to students pursuing a specific engineering major. }\end{array}$ \\
\hline $\begin{array}{l}\text { Responsiveness } \\
\text { of Students }\end{array}$ & $\begin{array}{l}\text { Women's responses also indicated that they considered themselves to be more } \\
\text { mature and responsible than their male counterparts. This led many to suspect that } \\
\text { the female students were simply more likely to register as early as possible, and } \\
\text { therefore, filled a disproportionate number of seats in a capped class. }\end{array}$ \\
\hline
\end{tabular}




\section{Conclusions}

Over the last six years, female enrollment in ECE490 / Innovation in the Engineering Design Process has increased steadily from $19 \%$ to $77 \%$. The multi-disciplinary course introduces design as a multi-disciplinary concept and is open to all engineering majors. The first half of the semester is offered on Valparaiso University's campus. Students then participate in a five-day field trip, traveling from our midwest campus to Disneyland ${ }^{\odot}$ Resort in Anaheim, California, or Walt Disney World ${ }^{\odot}$ Resort in Lake Buena Vista, Florida. At the parks, students participate in multiple workshops and tours focusing on engineering, design, creativity, innovation, leadership, teamwork, and communication. Sessions are led by either Valparaiso University's faculty or Disney Parks Cast Members. After returning to campus, students complete the final seven weeks of the semester at Valparaiso University.

To better understand why the class had a disproportionate female enrollment, interviews and surveys were conducted with female and male students and alumni. The results indicated that there was not a single, dominant factor that influenced the female or male enrollment. Rather, a combination of six different factors each increased the likelihood for a typical female student to enroll in the class and decreased the likelihood for a typical male student to enroll in the class.

\section{References}

1. M.M.Budnik, E.W.Johnson, "Inspiring Creativity for the Engineer of 2020," Proceedings of the IEEE Interdisciplinary Engineering Design Education Conference (IEDEC), Santa Clara, CA, March 19, 2012.

2. M.M.Budnik, "CreativEngineering for 2020," 2013 Education and Information Systems, Technologies, and Applications (EISTA), Orlando, FL, July 9-12, 2013.

3. C.Bradford, Z.Balgeman, M.King, S.Khorbotly, M.M.Budnik, "A Multidisciplinary Course for Developing, Nurturing, and Strengthening Student Creativity," Education and Information Systems, Technologies, and Applications (EISTA), Orlando, FL, July 15-18, 2014.

4. C.Bradford, Z.Balgeman, F.Aguilar, S.Khorbotly, M.M.Budnik, "A Problem-Solving Approach to Teaching Creativity for Engineering and Other Disciplines", Journal on Systemics, Cybernetics and Informatics, vol. 12, no. 4, 2014, pp. 13-17.

5. $\quad$ S.Khorbortly, M.M.Budnik, "Creative Engineering for 2020," Journal of Systemics, Cybernetics and Informatics, vol. 12, no. 1, 2014, pp. 82-90.

6. M.M.Budnik, "Extracurricular Field Trips to Theme Parks to Teach Creativity and Innovation," Proceedings of the 2015 ASEE Annual Conference, Seattle, WA, June 14-17, 2015. 